\title{
Stereotaktisk bestråling av columnametastaser
}

\author{
Strålebehandling som smertelindring ved columnametastaser er veldokumentert og i utstrakt bruk. Ved Oslo \\ universitetssykehus, Radiumhospitalet, tilbyr vi nå en variant av stereotaktisk strålebehandling som et alter- \\ nativ til konvensjonell strålebehandling. Vi beskriver her metoden og diskuterer hvilken ressursbruk som \\ kreves for å tilby et alternativt behandlingstilbud for en pasientgruppe med dårlig prognose, og som mange \\ også vil hevde har et bra konvensjonelt behandlingstilbud.
}

Ca. $10-30 \%$ av alle kreftpasienter utvikler metastaser i columna, og en stor andel av disse vil ha behov for palliativ strålebehandling i sykdomsforløpet pga. smerter, nerve- eller medullakompresjon (1). Formålet med strålebehandling mot skjelettmetastaser i columna er rask reduksjon av smerter, begrensning og/eller reversering av nevrologiske symptomer og å oppnå lokal kontroll. Effekten av dette er godt dokumentert $(2,3)$.

Konvensjonell strålebehandling med et enkelt feltoppsett innebærer en lite ressurskrevende planleggingsprosess og er et veletablert behandlingstilbud for disse pasientene. Man gir vanligvis ti daglige behandlinger à 3 gray (Gy), eller sjeldnere en engangsbehandling med $8 \mathrm{~Gy}$, og hele stråledosen gis inn rett bakfra. Siden medulla spinalis dermed uvegerlig blir liggende inne i det bestrålte området, må behandlingsdosen legges under den optimale terapeutiske dosen for å unngå overdosering til medulla (fig 1). Ryggmargen er et strålefølsomt organ, og for høye doser til denne kan i verste fall føre til lammelser. Muligheten for varig lokal tumorkontroll er derfor relativt liten (4-6). Dersom en tidligere bestrålt ryggradsmetastase øker i størrelse eller det oppstår metastaser i nabovirvler, kan kon- vensjonelle fraksjoneringer og behandlingsopplegg også være problematiske, siden effekten av tidligere strålebelastning på medulla i liten grad er reparert.

\section{Stereotaktisk strålebehandling}

Stereotaktisk strålebehandling er en avansert behandlingsform som de siste årene har økt betydelig i omfang og anvendelsesområder. Man bruker det samme utstyret og prinsippene som ved ordinær strålebehandling, men det leveres en høypresis behandling mot små områder, og man oppnår en skarpere avgrensning mellom det som skal bestråles og områder som bør unngås. Dette gjøres bl.a. ved å benytte mange feltinnganger og ekstra god fiksering av pasienten. Et eksempel på et slikt feltarrangement er vist i figur 2. Strålingsdosene ved stereotaktisk strålebehandling er vanligvis mye høyere enn for konvensjonelle behandlinger og kan leveres på ett eller få oppmøter for pasienten. Vanlig dose kan her være opptil 25 Gy gitt som en engangsbehandling.

Dette tilsvarer en langt høyere dose enn det som gis med fraksjonert behandling, siden den biologiske effekten ikke bare har sammenheng med totaldose, men også dose per fraksjon (7).

Stereotaktisk bestråling av columname- tastaser har blitt et alternativ for pasienter som tradisjonelt har fått konvensjonell strålebehandling (4). Dagens utstyr muliggjør en sikker fordeling av høye måldoser til en svulst tett på medulla spinalis. Ved bruk av stereotaktisk teknikk øker sannsynligheten for tumorkontroll og rask klinisk respons, og samtidig reduseres det uønskede dosebidraget til friskvev, spesielt til ryggmargen, men også til tarm, nyrer, lunge og spiserør (8). Behandling av områder som tidligere er behandlet, muliggjøres også i større grad enn ved konvensjonelle teknikker (9).

Mange studier har demonstrert at stereotaktisk columnabestråling er godt tolerert av pasientene, samt at resultatet av behandlingen er bedre enn konvensjonell behandling i form av mer langvarig tumorkontroll, uten økte bivirkninger (10-12). Pasienter som ville fått tilbud om strålebehandling over to uker, vil med denne metoden kunne få hele behandlingen gjennomført på en dag $(8,13)$.

\section{Vår fremgangsmåte}

De vanligste formene for stereotaktisk strålebehandling er forbundet med en mer omfattende planleggingsprosess og lengre tid i fiksert posisjon på behandlingsapparatet (45-60 $\mathrm{min})$ enn konvensjonell

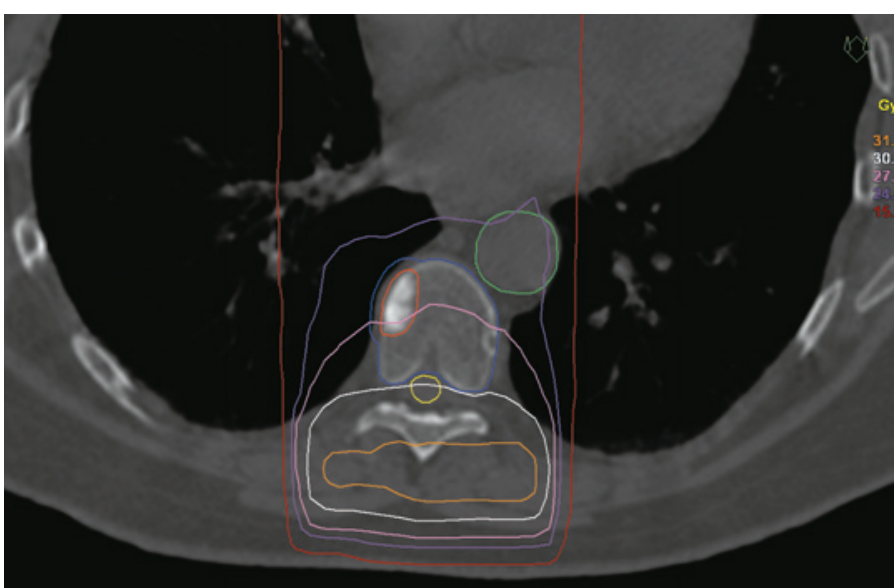

Figur 1 Eksempel på et konvensjonelt strålefelt. Bildet viser en metastase (rød) i columna og området som behandles (blått). Medulla spinalis er markert i gult og aorta i grønt. Strålingsdosen som gis innenfor den mørkerøde linjen er 15 Gy eller høyere. Tilsvarende er 24, 27, 30 og 31,5 Gy henholdsvis innenfor den lilla, rosa, hvite og oransje linjen. Det presiseres at dosefordelingen er den summerte dosen som gis over ti fraksjoner

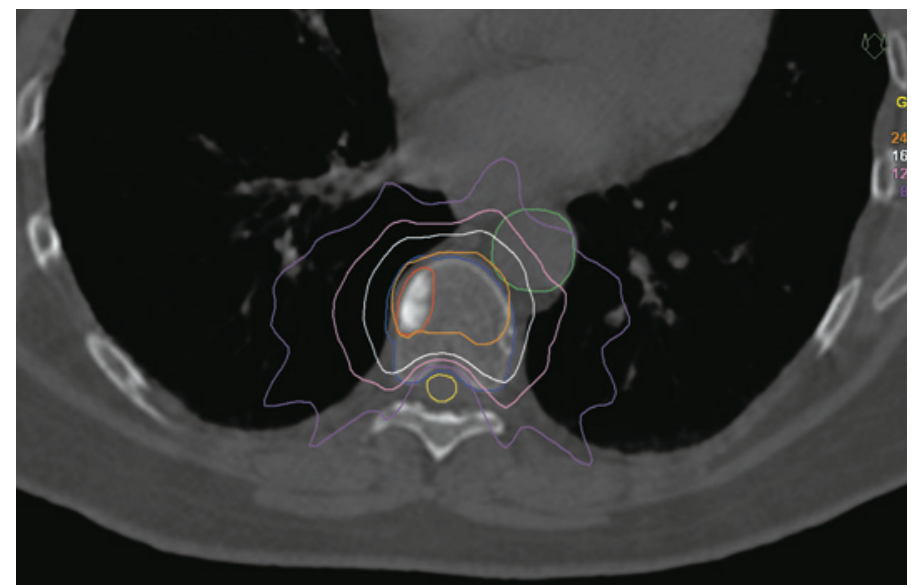

Figur 2 Eksempel på en doseplan ved stereotaktisk stråling. Strålingsdosen som gis innenfor den lilla linjen er 8 Gy eller høyere. Tilsvarende er 12, 16 og 24 Gy henholdsvis innenfor den rosa, hvite og oransje linjen. Behandlingen gis på ett oppmøte 
behandling. Denne tidsbruken kan være vanskelig å forsvare for en pasientgruppe med metastatisk sykdom $(14,15)$. Ved Oslo universitetssykehus, Radiumhospitalet, ønsket vi å benytte oss av de attraktive sidene stereotaktisk strålebehandling kan tilby, og samtidig ville vi prøve å forenkle prosessen, slik at denne metoden kunne bli et reelt alternativ til den konvensjonelle behandlingen pasientene tilbys - også når det gjelder behandlingskostnader.

Vi tilbyr nå behandling hvor den beregnede dosefordelingen er ekvivalent med høyavansert stereotaktisk behandling, mens planleggingsfasen er sammenliknbar med de enkle konvensjonelle metodene når det gjelder ressursbruk. Et vesentlig moment er at den beregnede dosen til medulla må holdes på et minimum, mens dosen til virvelen som behandles må være høy nok til å gi varig lokal effekt. Løsningen ble å lage et templatbasert behandlingsopplegg, altså et opplegg som i utgangspunktet er uavhengig av den enkelte pasient, men som med små justeringer kan tilpasses pasienten. Behandlingen gis med ni standardiserte feltvinkler, som gjør at strålingsdosen blir fordelt utenom medulla (fig 2). Resultatet ble en planleggingsprosess som i de fleste tilfeller tar 15-30 minutter, mens de mest vanlige planleggingsprotokollene ville krevd flere timer.

Den beregnede dosefordelingen gir betydelig høyere svulstdose, og en tilfredsstillende skjerming av risikoorganene i nærheten av behandlingsområdet, sett i forhold til konvensjonell behandling. Tumorområdet får over $18 \mathrm{~Gy}$ (midlere strålingsdose 24 Gy), mens medulla får maksimalt $12 \mathrm{~Gy}$. Til sammenlikning er dosefordelingen fra et tradisjonelt opplegg, der 30 Gy gis i ti fraksjoner, vist i figur 1 .

I tillegg til en betydelig økt tumordose, vil pasientene kun få ett behandlingsoppmøte - eller tre, for dem som er tidligere behandlet - der alternativene ofte ville vært ti oppmøter. Selv om dette ene oppmøtet er noe lengre enn ved konvensjonell fraksjonering - ca. 30-45 minutter mot 15 minutter - blir den totale behandlingstiden likevel langt kortere.

Vi mener med denne metoden å kunne tilby en behandling som tar mindre tid totalt sett for pasienten og at ressursbruken er akseptabel.

\section{Einar Waldeland}

einar.waldeland@ous-hf.no

Odd Terje Brustugun

Christina Ramberg

Åslaug Helland

Einar Waldeland (f. 1980) er ph.d i strålingsfysikk og arbeider som medisinsk fysiker ved Avdeling for medisinsk fysikk, Oslo universitetssykehus, Radiumhospitalet.

Odd Terje Brustugun (f. 1970) er onkolog, dr.med. og overlege ved Avdeling for kreftbehandling, Oslo universitetssykehus, Radiumhospitalet.

Christina Ramberg (f. 1967) er dr.scient. i biofysikk og arbeider som medisinsk fysiker ved Avdeling for medisinsk fysikk, Oslo universitetssykehus, Radiumhospitalet.

Åslaug Helland (f. 1966) er onkolog, dr.med. og overlege ved Avdeling for kreftbehandling, Oslo universitetssykehus, Radiumhospitalet.

\section{Litteratur}

1. Fornasier VL, Horne JG. Metastases to the vertebral column. Cancer 1975; 36: 590-4.

2. Faul CM, Flickinger JC. The use of radiation in the management of spinal metastases. J Neurooncol 1995: 23: 149-61.

3. Loblaw DA, Laperriere NJ. Emergency treatment of malignant extradural spinal cord compression an evidence-based guideline. J Clin Oncol 1998; 16: $1613-24$.
4. Gerszten PC, Mendel E, Yamada Y. Radiotherapy and radiosurgery for metastatic spine disease: what are the options, indications, and outcomes? Spine 2009; 34 (suppl): 78-92.

5. Kim YH, Fayos JV. Radiation tolerance of the cervical spinal cord. Radiology 1981; 139: 473-8.

6. Rades D, Stalpers LJA, Veninga T et al. Evaluation of five radiation schedules and prognostic factors for metastatic spinal cord compression. J Clin Oncol 2005: 23: 3366-75.

7. Park C, Papiez L, Zhang S et al. Universal survival curve and single fraction equivalent dose: useful tools in understanding potency of ablative radiotherapy. Int J Radiat Oncol Biol Phys 2008; 70 : 847-52.

8. Benzil DL, Saboori M, Mogilner AY et al. Safety and efficacy of stereotactic radiosurgery for tumors of the spine. J Neurosurg 2004; 101 (suppl 3): 413-8.

9. Sahgal A, Ames C, Chou D et al. Stereotactic body radiotherapy is effective salvage therapy for patients with prior radiation of spinal metastases. Int J Radiat Oncol Biol Phys 2009; 74: 723-31.

10. Gerszten PC, Burton SA, Ozhasoglu C et al. Radiosurgery for spinal metastases: clinical experience in 500 cases from a single institution. Spine 2007; 32: $193-9$.

11. Sahgal A, Larson DA, Chang EL. Stereotactic body radiosurgery for spinal metastases: a critical review. Int J Radiat Oncol Biol Phys 2008: 71 : review. 652 - 65.

12. Chang EL, Shiu AS, Lii MF et al. Phase I clinical evaluation of near-simultaneous computed tomographic image-guided stereotactic body radiotherapy for spinal metastases. Int J Radiat Oncol Biol Phys 2004; 59: 1288-94.

13. Gerszten PC, Welch WC. Cyberknife radiosurgery for metastatic spine tumors. Neurosurg Clin N Am 2004: 15: 491-501.

14. Haley ML, Gerszten PC, Heron DE et al. Efficacy and cost-effectiveness analysis of external beam and stereotactic body radiation therapy in the treatment of spine metastases: a matched-pair analysis. J Neurosurg Spine 2011: 14: 537-42.

15. Lo SS, Sahgal A, Hartsell WF et al. The treatment of bone metastasis with highly conformal radiation therapy: a brave new world or a costly mistake? Clin Oncol (R Coll Radiol) 2009; 21: 662-4.

Mottatt 17.8. 2012, første revisjon innsendt 26.9 2012, godkjent 30.10. 2012. Medisinsk redaktør Kristin Viste.

Publisert først på nett 7.11. 2012. 